\title{
Porphyrin biosynthesis in the erythrocytes of patients with sideropenic anaemias
}

\author{
O. GUTNIAK, M. KOPEĆ, AND J. NIECZAJ \\ From the Department of Radiobiology and Health Protection, Institute of Nuclear Research, and the \\ Department of Haematology, Institute of Rheumatology, Warsaw, Poland
}

SYNOPSIS The ability of erythrocytes to synthesize porphyrins from $\delta$-aminolaevulic acid was com-i pared in healthy people, patients with true iron-deficiency anaemia, and anaemic patients with rheumatoid arthritis. Porphyrin synthesis was found to be impaired in true iron deficiency but not in rheumatoid arthritis cases showing a similar degree of anaemia. The $\delta$-aminolaevulic acid dehydra- $\circ$

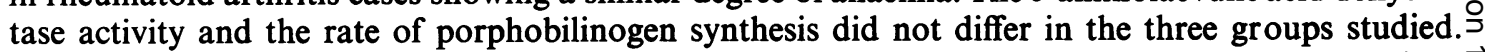
The most probable mechanism of impairment of porphyrin synthesis in the anaemia of true iron $\vec{z}$ deficiency seems to be a partial block in the conversion of porphobilinogen into porphyrins. High endogenous and exogenous protoporphyrin concentration did not affect the synthesis of porphyrins.

The mature red cell contains a system of cytoplasmic enzymes capable of catalysing the synthesis of porphyrins from $\delta$-aminolaevulic acid. Biosynthesis of porphyrins has been found to be decreased in erythrocytes of patients with iron-deficiency anaemia (Lichtman and Feldman. 1963; Heilmeyer, 1964; Prato, Mazza, Massaro, Bianco, and Battistini, 1968). Heilmeyer (1964) suggested that the diminished biosynthesis of porphyrins may be attributed to an inhibitory action of accumulated protophorphyrin on the $\delta$-aminolaevulic acid to porphobilinogen conversion through a negative feedback mechanism. This inhibitory action of protoporphyrin was demonstrated in experiments in vitro, in which haemolysed red blood cells were incubated with $\delta$-aminolaevulic acid in the presence of added protoporphyrin.

Severe anaemia accompanying chronic inflammatory diseases shares many features in common with anaemia of true iron deficiency. Thus, in the anaemia accompanying rheumatoid arthritis, which may be considered as a typical representative of anaemia of chronic inflammatory states, low serum iron, hypochromia of erythrocytes, and the accumulation of free erythrocyte protoporphyrin are common findings. The endogenous deficiency of iron for erythropoiesis due to impaired reutilization of the iron liberated from effete blood cells is considered to be an essential pathogenic factor in this anaemia of chronic inflammation (Haurani, Burke, and Martinez, 1965; Owen and Lawson, 1966).

Received for publication 8 September 1970.
The beneficial if transient effect of parenteral treatment with iron preparations observed in anaemic patients with rheumatoid arthritis is in agreemento with this assumption. Therefore, a study was under-市 taken to establish whether impaired porphyrin synthesis could be observed in the erythrocytes from anaemic patients with rheumatoid arthritis. These were compared with the erythrocytes from normat subjects and patients with anaemia due to chronic bleeding.

\section{Materials}

Blood from the following groups of subjects was used in the study.

ADVANCED ACTIVE RHEUMATOID ARTHRITISO The blood samples were taken from seven patients before treatment with iron.

ANAEMIA DUE TO CHRONIC BLEEDING

Four patients had a history of recurrent haemor- rhages from oesophageal hernia, rectal varices, or duodenal ulcer for at least three years. The haema $\frac{1}{\mathbb{D}}$ tological findings in the two groups of patients are? presented in Table I.

CONTROLS

Five female and five male blood donors without anyo haematological abnormalities served as controf groups. 
The ages of the patients and blood donors ranged from 30 to 55 years.

\section{Methods}

Serum iron was measured by the method of Schalles (1958). The activity of $\delta$-aminolaevulic acid-dehydratase was determined by the method of Granick and Mauzerall (1958). Free erythrocyte protoporphyrin in intact erythrocytes was measured according to the method of Gutniak (1959). The content of $\delta$-aminolaevulic acid, porphobilinogen, uroporphyrin, coproporphyrin, and protoporphyrin in the incubation mixture was determined according to the method of Gutniak and Kowalski (1966) modified so that $50 \%$ instead of a $30 \%$ solution of trichloroacetic acid was added for deproteinization (final concentration $5 \% \mathrm{w} / \mathrm{v}$ ) and for the elution of uroporphyrin adsorbed on talc $5 \% \mathrm{NH}_{4} \mathrm{OH}$ was replaced by a mixture of $1 \mathrm{~N}=\mathrm{HCl}$ and acetone $(1: 9, \mathrm{v} / \mathrm{v})$. The eluate was washed with ether. From the acid aqueous solution $(p \mathrm{H} \mathrm{3.0)}$ uroporphyrin was then transferred to ethyl acetate and subsequently to $2 \% \mathrm{HCl}$.

The concentrations of porphobilinogen and porphyrins, corrected by subtraction of the control values, were expressed as micrograms of $\delta$-aminolaevulic acid per $100 \mathrm{ml}$ of packed erythrocytes used for their formation.

Venous blood was withdrawn into heparin. The plasma and buffy coat were separated by centrifugation and removed. The red cells were washed twice with saline, suspended in $\mathrm{H}_{2} \mathrm{O}\left(2 \cdot 1 \mathrm{ml}\right.$ of $\mathrm{H}_{2} \mathrm{O}$ for $1 \mathrm{ml}$ of packed erythrocytes) and allowed to haemolyse for one hour at $0^{\circ} \mathrm{C}$.

Before incubation aliquots of the haemolysate each of $1.55 \mathrm{ml}$ (corresponding to $0.5 \mathrm{ml}$ of packed cells) were pipetted into $25 \mathrm{ml}$ flasks and brought to approximate isotonicity with $0.27 \mathrm{ml}$ of 0.15 M-phosphate buffer, containing $0.483 \mathrm{M}-\mathrm{KCl}$. To the haemolysate $0.133 \mathrm{mg}$ or alternatively $0.067 \mathrm{mg} \delta$ aminolaevulic acid- $\mathrm{HCl}$ (neutralized with $\mathrm{NaHCO}_{3}$ ), $0.75 \mathrm{mg}$ of glucose, and $2.03 \mathrm{mg}$ of $\mathrm{MgCl}_{2} \cdot 6 \mathrm{H}_{2} \mathrm{O}$, all dissolved in $0.122 \mathrm{M}-\mathrm{KCl}$, were added. The final $p \mathrm{H}$ of the incubation mixture was $7 \cdot 4$. The final volume was made up to $2 \cdot 8 \mathrm{ml}$ with $0 \cdot 122 \mathrm{M}-\mathrm{KCl}$.

The flasks were plugged with cottonwool and kept overnight in an ice-bath. On the next day they were incubated in a shaking water bath at $38^{\circ} \mathrm{C}$ for one to six hours. Overnight storage in the cold before incubation had a negligible effect on the yield of porphyrins and their precursors compared with experiments in which the samples were incubated immediately after preparation. Overnight storage was therefore adopted to allow the time-consuming incubation and analytical procedures to be performed the next day.

Our analytical procedure, although timeconsuming, has the advantage of allowing determination of the porphyrins and their precursors by separation from a single samplefollowing incubation.

\section{Results and Discussion}

Results of routine haematological determinations in the patients studied showed (Table I) that four cases each with chronic bleeding and rheumatoid arthritis had a pronounced anaemia with $\mathrm{Hb}$ concentration below $9 \mathrm{~g} \%$ and PCV values below $35 \%$. Anaemia in three other patients with rheumatoid arthritis was marked but less sever $\epsilon$. However, in all these

\begin{tabular}{|c|c|c|c|c|c|c|c|c|}
\hline Group & $H b(g \%)$ & $\begin{array}{l}\text { Erythrocytes } \\
\left(10^{4} / \mathrm{mm}^{3}\right)\end{array}$ & $\begin{array}{l}\text { Haematocrit } \\
(\%)\end{array}$ & $\begin{array}{l}M C V \\
\left(\mu^{3}\right)\end{array}$ & $\begin{array}{l}M C H C \\
(\%)\end{array}$ & $\begin{array}{l}\text { Reticulo- } \\
\text { cytes } \\
(\%)\end{array}$ & $\begin{array}{l}\text { Serum Iron } \\
(\mu g \%)\end{array}$ & $\begin{array}{l}\text { Free Erythro- } \\
\text { cyte Proto- } \\
\text { porphyrin } \\
(\mu \mathrm{g} \%)\end{array}$ \\
\hline $\begin{array}{l}\text { Chronic bleeding } \\
\text { Chronic bleeding } \\
\text { Chronic bleeding } \\
\text { Chronic bleeding } \\
\text { Rheumatoid arthritis } \\
\text { Rheumatoid arthritis } \\
\text { Rheumatoid arthritis } \\
\text { Rheumatoid arthritis } \\
\text { Rheumatoid arthritis } \\
\text { Rheumatoid arthritis } \\
\text { Rheumatoid arthritis }\end{array}$ & $\begin{array}{l}6 \cdot 96 \\
5 \cdot 66 \\
6 \cdot 82 \\
8 \cdot 41 \\
6 \cdot 67 \\
5 \cdot 66 \\
7 \cdot 83 \\
10 \cdot 0 \\
7 \cdot 69 \\
9 \cdot 72 \\
9 \cdot 86\end{array}$ & $\begin{array}{l}3 \cdot 15 \\
3 \cdot 09 \\
3 \cdot 18 \\
4 \cdot 09 \\
3 \cdot 92 \\
3 \cdot 40 \\
3 \cdot 49 \\
4 \cdot 34 \\
3 \cdot 09 \\
3 \cdot 63 \\
3 \cdot 83\end{array}$ & $\begin{array}{l}30 \\
25 \\
23 \\
33 \\
31 \\
27 \\
30 \\
43 \\
31 \\
34 \\
36\end{array}$ & $\begin{array}{r}95 \\
81 \\
73 \\
81 \\
79 \\
81 \\
86 \\
99 \\
102 \\
95 \\
94\end{array}$ & $\begin{array}{l}23 \\
23 \\
29 \\
25 \\
21 \\
21 \\
26 \\
23 \\
24 \\
28 \\
27\end{array}$ & $\begin{array}{l}1 \cdot 7 \\
1 \cdot 3 \\
1 \cdot 5 \\
0.6 \\
2.0 \\
1.4 \\
1.2 \\
1 \cdot 8 \\
0 \cdot 6 \\
1 \cdot 8 \\
1 \cdot 1\end{array}$ & $\begin{array}{l}12 \\
42 \\
25 \\
20 \\
18 \\
16 \\
24 \\
38 \\
12 \\
56 \\
39\end{array}$ & $\begin{array}{r}120 \\
299 \\
310 \\
243 \\
284 \\
200 \\
376 \\
93 \\
90 \\
53 \\
20\end{array}$ \\
\hline $\begin{array}{l}\text { Controls } \\
\text { Men } \\
\text { Women }\end{array}$ & 16 & $5 \cdot 4$ & 46 & 86 & 34 & $\begin{array}{l}0.6 \\
0.9\end{array}$ & $\begin{array}{l}100 \\
100\end{array}$ & 28 \\
\hline
\end{tabular}

Table I Routine haematological determination, serum iron, and free erythrocyte protoporphyrin

${ }^{1}$ Mean normal values of haematological indices for Polish populations from the work of Pawelski and Zawadzki (1958) and of free erythrocyte protoporphyrin from Gutniak (1959). 


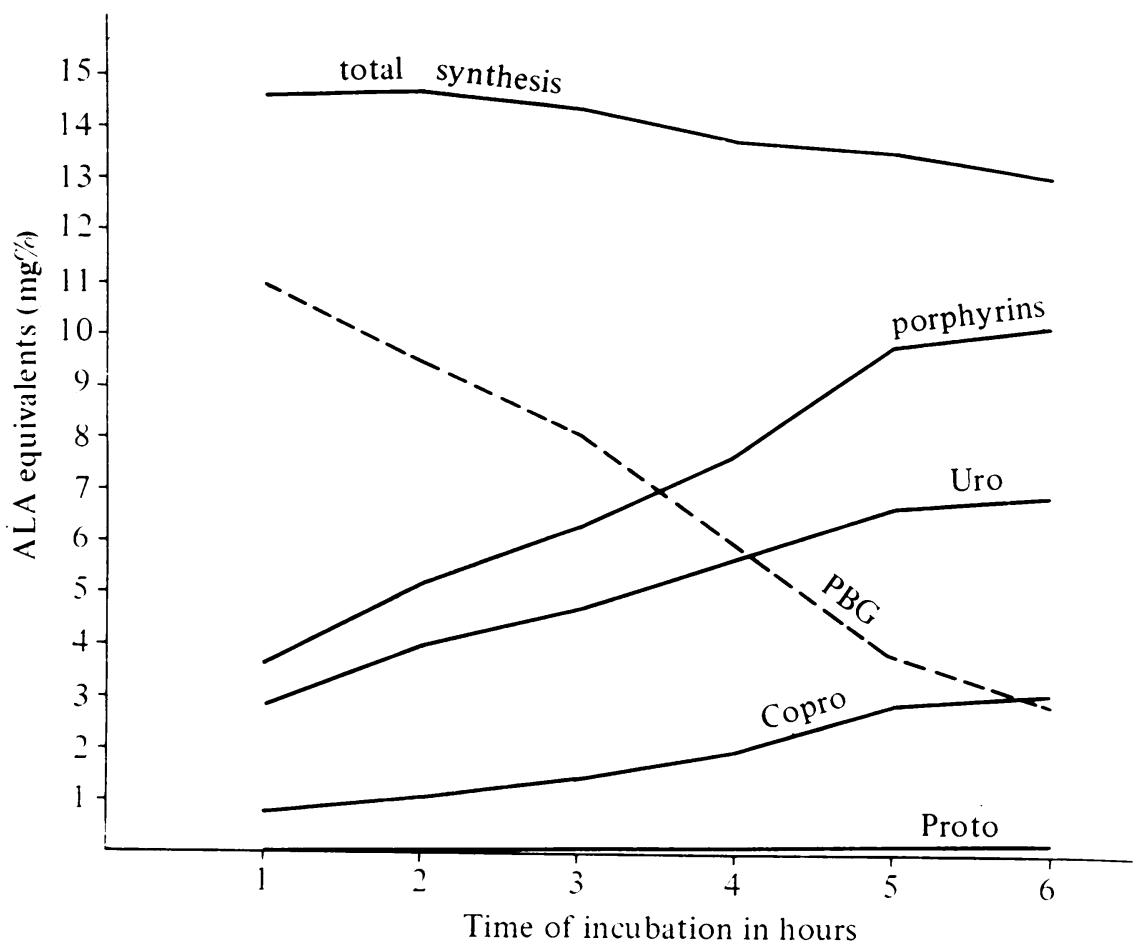

Fig. 1. Formation of porphyrins and disappearance of porphobilinogen in a haemolysate of normal erythrocytes incubated with $20 \mathrm{mg} \%$ of $\delta$-aminolaevulic acid. $A L A=\delta$-aminolaevulic acid

$P B G=$ porphobilinogen Uro $=$ uroporphyrin Copro = coproporphyrin Proto $=$ protoporphyrin

cases the decrease in mean cell haemoglobin concentration and the decrease in serum iron level were similar. Rather low reticulocyte counts were noted in both groups of patients. The free erythrocyte protoporphyrin level was markedly raised in all but two patients, the elevation being more pronounced in cases with severe anaemia.

The porphyrin-synthesizing ability of erythrocytes from the groups of patients described above was compared with that of normal erythrocytes. As can be seen from Table II, haemolysates of normal erythrocytes are quite efficient in the production of porphyrins. It is noteworthy that the production of porphyrins varied very little between blood donors apart from a sex difference; female erythrocytes have been found more active in this respect.

The effect of incubation time on the formation of porphobilinogen and porphyrins is recorded in Figure 1. It can be concluded that during the first hour of incubation the production of porphobilinogen reaches its maximum and its conversion to porphyrin begins. In the subsequent hours there is a steady

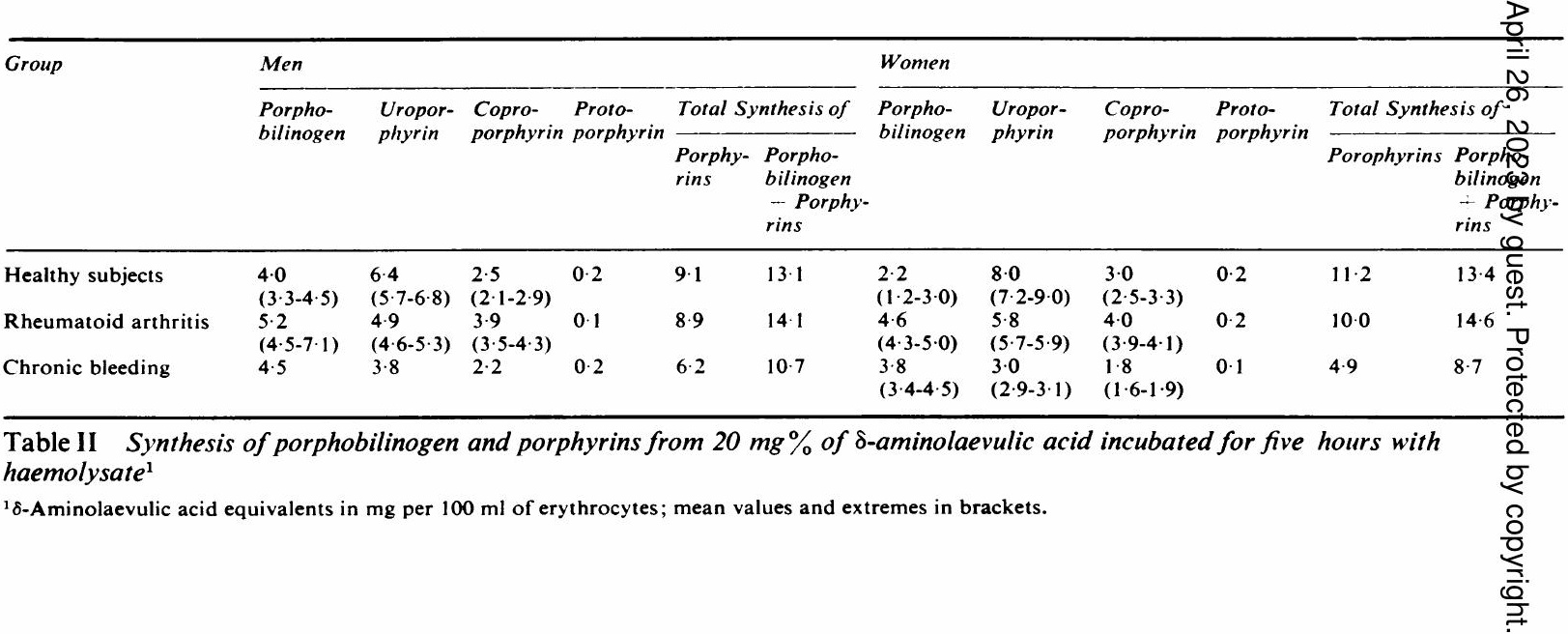




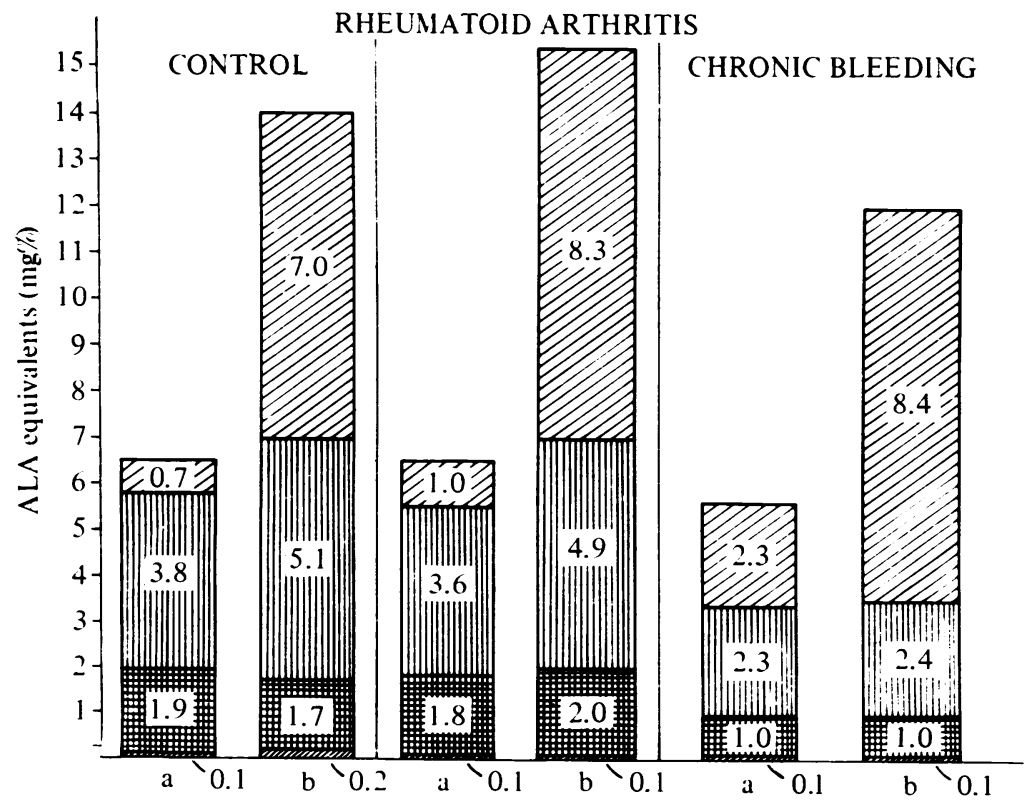

Fig. 2. The influence of substrate concentration on the production of porphobilinogen and porphyrins by haemolysate of erythrocytes of healthy subjects and patients with rheumatoid arthritis and with chronic bleeding. Mean values are given of experiments performed with $10 \mathrm{mg} \%$ and $20 \mathrm{mg} \%$ of $\delta$-aminolaevulic acid after three hours' incubation.

\begin{abstract}
a $10 \mathrm{mg} \%$
b $20 \mathrm{mg} \%$
\end{abstract}
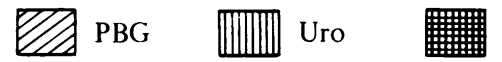

Copro increase in porphyrin formation and decrease in porphobilinogen level. After six hours of incubation porphobilinogen decreases to a low value, and the synthesis for porphyrins levels off. Table II contains data for porphyrin synthesis in pathological erythrocytes. Comparing these data with normal values one can see that erythrocytes from rheumatoid arthritis serum exhibit an unchanged ability to synthesize porphyrins, while erythrocytes from cases of chronic bleeding are markedly impaired in this respect. From the relative amounts of porphobilinogen and porphyrins produced at different concentrations of $\delta$-aminolaevulic acid in the control system, it can be inferred that the conversion rate differs for each step in the synthesis of porphyrins from $\delta$-aminolaevulic acid (Fig. 2). The highest is that for conversion of $\delta$-aminolaevulic acid to porphobilinogen, the lowest that of uroporphyrinogen to coproporphyrinogen.

The amounts of protoporphyrin formed were relatively small and almost independent of the amount of substrate added to the system and the time of incubation (Figs. 1 and 2).

The same effect was also observed in erythrocytes from cases of rheumatoid arthritis but when erythrocytes from cases of chronic bleeding were used the conversion of porphobilinogen to uroporphyrinogens and thence to coproporphyrinogens was impaired and not dependent on the concentration of $\delta$-aminolaevulic acid.

Since the synthesis of porphyrins in erythrocytes of patients with rheumatoid arthritis with severe anaemia in spite of their very high free erythrocyte protoporphyrin was nearly equal to control values

\begin{tabular}{|c|c|c|c|c|}
\hline \multirow[t]{2}{*}{$\begin{array}{l}\text { Protoporphyrin Added } \\
(\mu \mathrm{g} / 100 \mathrm{ml} \text { erythrocytes) }\end{array}$} & \multirow[t]{2}{*}{$\begin{array}{l}\text { Protoporphyrin (concentration } \\
\mu \mathrm{g} / 100 \mathrm{ml} \text { erythrocytes) }\end{array}$} & \multicolumn{3}{|c|}{$\begin{array}{l}\text { End Products } \\
\text { (mean values in } \delta \text {-aminolaevulic acid equivalents in } m g \% \text { ) }\end{array}$} \\
\hline & & Porphobilinogen & Porphyrins & $\begin{array}{l}\text { Porphobilinogen }+ \\
\text { Porphyrins }\end{array}$ \\
\hline $\begin{array}{l}0 \\
500 \\
1,000\end{array}$ & $\begin{array}{l}25 \\
525 \\
1,025\end{array}$ & $\begin{array}{l}4 \cdot 0 \\
4 \cdot 1 \\
3 \cdot 9\end{array}$ & $\begin{array}{l}9 \cdot 0 \\
9 \cdot 3 \\
9 \cdot 1\end{array}$ & $\begin{array}{l}13 \cdot 2 \\
13 \cdot 4 \\
13 \cdot 0\end{array}$ \\
\hline
\end{tabular}

Table III Influence of added protoporphyrin on the synthesis of porphobilinogen and porphyrins by haemolysate of normal erythrocytes incubated with $20 \mathrm{mg} \%$ of $\delta$-aminolaevulic acid for five hours 


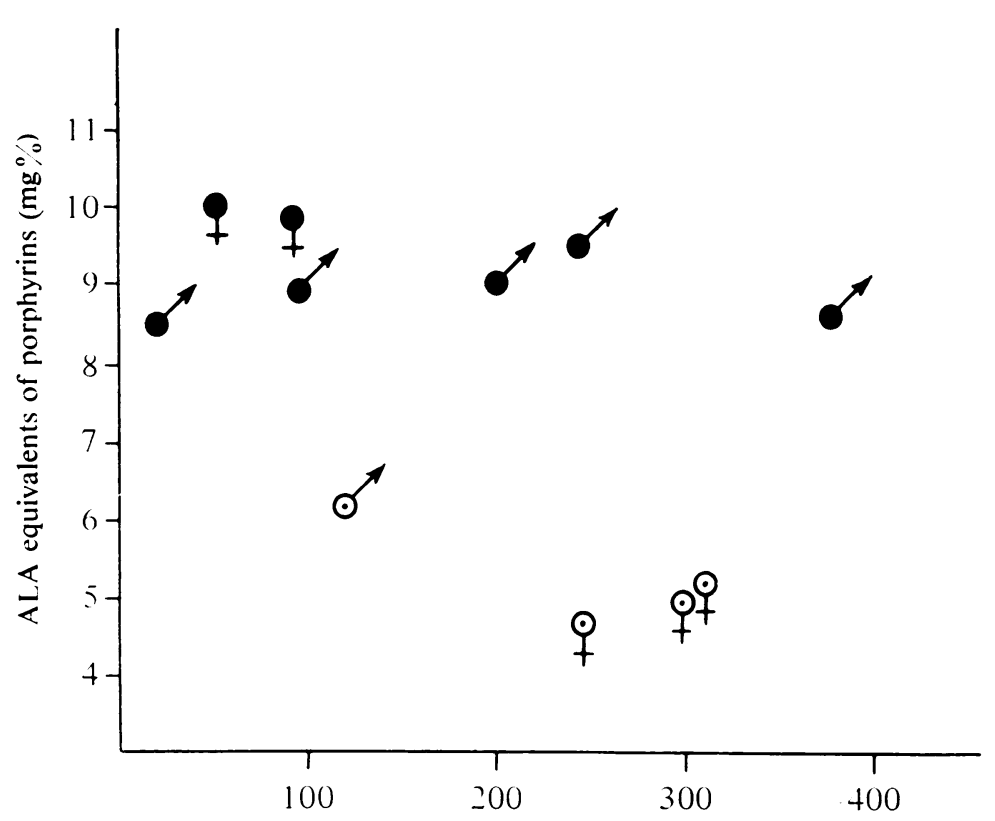

Fig. 3. The relationship between the total synthesis of porphyrins and the endogenous free erythrocyte protoporphyrin concentration. Haemolysate incubated with $20 \mathrm{mg} \%$ of $\delta$-aminolaevulic acid for five hours. $0=$ Rheumatoid arthritis; $\bigcirc=$ chronic bleeding.

experiments were undertaken to check whether increased concentrations of exogenous protoporphyrin in the system containing haemolysate of normal erythrocytes can inhibit their ability to synthesize porphyrins. Results obtained showed (Table III) that the addition of protoporphyrin up to $1000 \mu \mathrm{g} \%$ did not affect the porphyrin produced from $\delta$-aminolaevulic acid. This result, together with the lack of any correlation between the level of endogenous free erythrocyte protoporphyrin and porphyrin production (Fig. 3), argues strongly against the suggestion that an increased level of protoporphyrin inhibits porphyrin synthesis. According to Heilmeyer (1964), lowered porphyrin synthesis might result from the decreased activity of $\delta$-aminolaevulic acid dehydratase, caused by accumulated protoporphyrin. Heilmeyer (1964) himself, however, could not demonstrate diminished activity of $\delta$-aminolaevulic acid dehydratase in erythrocytes of sideropenic patients. Lichtman and Feldman (1963) found also that the activity of $\delta$-aminolaevulic acid dehydratase in erythrocytes from iron-deficiency anaemia did not differ from normal values.

We were able to show that $\delta$-aminolaevulic acid dehydratase activity of erythrocytes from patients with chronic bleeding and with rheumatoid arthritis was not impaired and that high concentrations of protoporphyrin added to the haemolysate of normal red blood cells did not influence their $\delta$-aminolaevulic

\begin{tabular}{|c|c|c|}
\hline Erythrocytes & $\begin{array}{l}\text { Protoporphyrin } \\
\text { ( } \mu \mathrm{g} / 100 \mathrm{ml} \\
\text { erythrocytes })\end{array}$ & $\begin{array}{l}\delta \text {-Aminolaevulic } \\
\text { Acid-dehydratase } \\
\text { Activity }(\mu M \\
P B G / m l / h r)\end{array}$ \\
\hline $\begin{array}{l}\text { Healthy subjects } \\
\text { Healthy subjects with } \\
500 \mu \mathrm{g} \% \text { of protoporphyrin }\end{array}$ & 30 & 0.97 \\
\hline $\begin{array}{l}\text { added } \\
\text { Cases of rheumatoid } \\
\text { arthritis }\end{array}$ & 310 & 0.98 \\
\hline Chronic bleeding cases & 304 & 0.96 \\
\hline
\end{tabular}

Table IV $\delta$-Aminolaevulic acid dehydratase activity in erythrocytes with high endogenous free erythrocyte protoporphyrin and in normal erythrocytes with added protoporphyrin

dehydratase activity (Table IV). It was the same as in a system without added protoporphyrin. There- 0 fore, the most probable site of partial block in $\omega$ porphyrin synthesis in chronic bleeding cases might be the conversion of porphobilinogen to uropor- 6

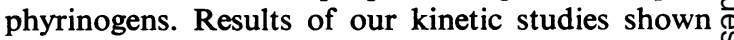
in Fig. 4 indicate that the production and the dis-? appearance of porphobilinogen follow the same $\frac{T}{0}$ pattern in all three groups studied. The percentage $\underset{\mathbb{D}}{\stackrel{O}{D}}$

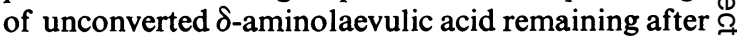
incubation was also the same in all three types of $\stackrel{\mathbb{Q}}{\varrho}$ erythrocytes. The balance studies show (Table V) that the 'loss' of $\delta$-aminolaevulic acid not converted $\delta$ 


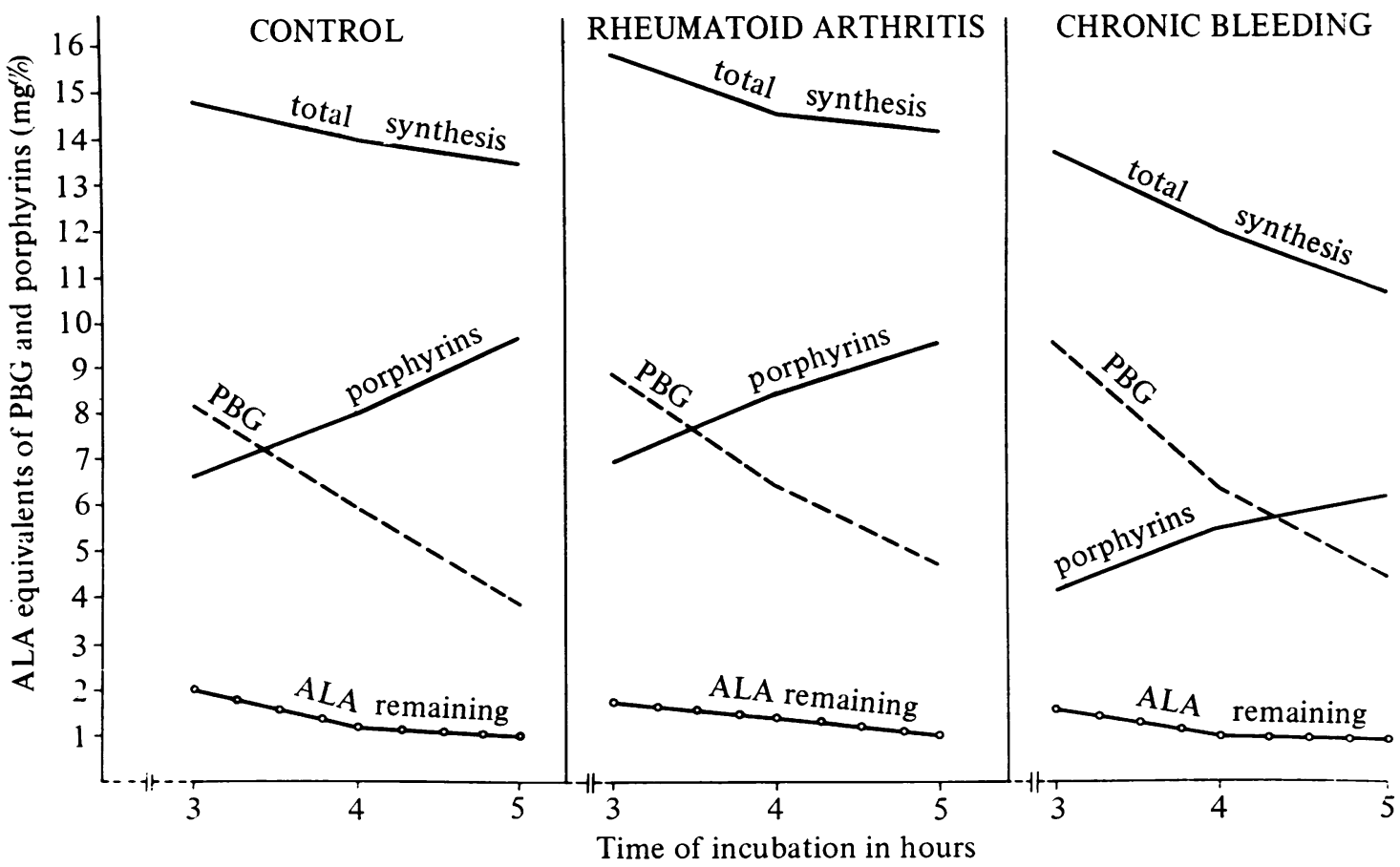

Fig. 4. Formation of porphyrins and disappearance of porphobilinogen during incubation of haemolysate of red blood cells from controls, chronic bleeding cases, and rheumatoid arthritis patients with $20 \mathrm{mg} \%$ of $\delta$-aminolaevulic acid.

\begin{tabular}{|c|c|c|c|c|}
\hline \multirow[t]{2}{*}{ Group } & \multicolumn{3}{|c|}{ Percentage of 8-Aminolaevulic Acid Recovered as } & \multirow{2}{*}{$\begin{array}{l}\text { Percentage of } \\
\text { Unrecovered } \\
\delta \text {-Aminolaevulic Acid } \\
\text { (Loss) }\end{array}$} \\
\hline & $\delta$-Aminolaevulic Acid & $\begin{array}{l}\text { Porphobilinogen }+ \\
\text { Porphyrins }\end{array}$ & Total & \\
\hline $\begin{array}{l}\text { Control } \\
\text { Rheumatoid arthritis } \\
\text { Chronic bleeding }\end{array}$ & $\begin{array}{l}4 \cdot 8 \\
4 \cdot 5 \\
4 \cdot 4\end{array}$ & $\begin{array}{l}67 \\
73 \\
46\end{array}$ & $\begin{array}{l}72 \\
78 \\
51\end{array}$ & $\begin{array}{l}28 \\
22 \\
49\end{array}$ \\
\hline
\end{tabular}

Table V Loss of $\delta$-aminolaevulic acid during five hours' incubation of haemolysate with $20 \mathrm{mg} \%$-aminolaevulic acid $^{1}$

${ }^{1}$ Mean values from four experiments in each group studied

to porphobilinogen and porphyrins was below $30 \%$ for control and rheumatoid arthritis erythrocytes while about a $50 \%$ 'loss' was observed in those of cases of chronic bleeding.

Since we have found that $\delta$-aminolaevulic acid and porphobilinogen were not degraded during five hours' incubation with boiled haemolysates and neither were porphyrins incubated with haemolysates of normal erythrocytes (Gutniak, 1969), we suggest that in normal erythrocytes there exists a mechanism which is capable of converting porphobilinogen to products other than porphyrins. This side pathway of porphobilinogen conversion seems to be more active in erythrocytes from patients with anaemia due to chronic bleeding than in normal erythrocytes or those from patients with rheumatoid arthritis.

From the presented results it may be concluded that in respect of porphyrin-synthesizing ability a distinct difference exists between erythrocytes from patients with chronic bleeding and those with the anaemia of rheumatoid arthritis, although the latter is postulated to result from a deficiency in iron available for erythropoiesis (Haurani et al, 1965; Owen and Lawson, 1966).

In connexion with this observation it should be emphasized that there is no agreement about the 
intraerythroblastic pool of iron in anaemia accompanying chronic inflammatory states, particularly rheumatoid arthritis. Formerly accepted views that the number of sideroblasts is decreased and that there exists a shift of iron from the intraerythroblastic pool into the extraerythroblastic one, namely, into reticuloendothelial cells of the bone marrow (Kaplan, Zuelzer, and Mouriquand, 1954; Mouriquand, 1958; Mouriquand, Lejeune, Germain, and Maitrepierre, 1962; Larizza and Orlandi, 1964), is no longer generally accepted. Bessis and BretonGorius (1961 and 1962) have observed large amounts of ferritin dispersed in the cytoplasm of erythroblasts from patients with inflammatory diseases. Mikołajew, Płachecka, Piotrowska, Gałajowa, and Kopeć (1966) found not only fairly high percentages of typical sideroblasts but also the ring type ones in myelograms of patients with rheumatoid arthritis. Several authors include the anaemia of rheumatoid arthritis in the group of secondary sideroblastic or sideroachrestic anaemias (Gibbon and Mollin, 1965; Mollin, 1965; Cartwright, 1968).

A number of defects in haem synthesis has been postulated in red cell precursors from patients with acquired sideroblastic anaemia (Steiner, Baldini, and Dameshek, 1963; Bessis and Jensen, 1965; Bousser, Gajdos, Gajdos- Török, Bilski-Pasquier, and Zittoun, 1967). However, Vavra and Poff (1967) failed to demonstrate any deficiency in the steps of haem synthesis between $\delta$-aminolaevulic acid and haem in erythrocytes from 10 patients with acquired sideroblastic anaemia.

Similarly we were not able to detect any disturbances in porphyrin synthesis from $\delta$-aminolaevulic acid in erythrocytes from patients with rheumatoid arthritis. This normal synthesis of porphyrins differentiates erythrocytes of patients with rheumatoid arthritis from those of true irondeficiency anaemia. It seems that besides relative iron deficiency for erythropoiesis other mechanisms must contribute to hypochromia and low haemoglobin content in the erythrocyte of the anaemia of rheumatoid arthritis.

\section{References}

Bessis, M. C., and Breton-Gorius, J. (1961). L'Ilot érythroblastique et la rheophéocytose de la ferritine dans l'inflammation. Nour. Rev. franc. Hémat., 1, 569-582.
Bessis, M. C., and Breton-Gorius, J. (1962). Iron metabolism in the bone marrow as seen by electron microscopy: a critical review. 으 Blood, 19, 635-663.

Bessis, M. C., and Jensen, W. N. (1965). Sideroblastic anaemia, mito- $\overrightarrow{\bar{Z}}$ chondria and erythroblastic iron. Brit. J. Haemat., 11, 49-51. O)

Bousser, J., Gajdos, A., Gajdos-Török, M., Bilski-Pasquier, G.. and Zittoun. R. (1967). Anémie sidéroblastique idiopathique aoquise: incorporation de la glycine-2-C-14 dans l'hème et la globine des érythroblastes médullaires in vitro. Nour. rev. frans. Hemat., 7, 847-854.

Cartwright, G. E. (1968). The anemia of chronic disorders. Semin. Hemat., 3, 351-375.

Granick. S., and Mauzerall. D. (1958). Porphyrin biosynthesis in $\mathscr{C}$ erythrocytes. II. Enzymes converting $\delta$-aminolevulinic acid to $\vec{O}$ coproporphyrinogen. J. hiol. Chem., 232, 1119-1140.

Gutniak, O. (1959). Oznaczanie i normalne zawartośsi wolnych porfiryn w czerwonych krwinkach ludzi zdrowych. Med. Pracy. $\omega$ $10,407-417$.

Gutniak, O. (1969). Unpublished results.

Gutniak, O., and Kowalski, E. (1966). Isolation and determination of porphyrins and their precursors in tissue. Analyt. Biochem., 16. N

20-28.
Haurani, F. I., Burke, W.. and Martinez, E. J. (1965). Defective reutilization of iron in the anemia of inflammation. J. Lab. clin. Med., 65, 560-570.

Heilmeyer, L. (1964). Die Störungen der Bluthämsynthese. Thieme, 음 Stuttgart.

Kaplan, E., Zuelzer, W. W.. and Mouriquand, C. (1954). Sideroblasts: a study of stainable nonhemoglobin iron in marrow normo- $\bar{z}$ blasts. Blood, 9, 203-213.

Larizza, P.. and Orlandi, F. (1964). Electron microscopic observations on bone marrow and liver tissue in non-hereditary refractory $\overrightarrow{0}$ sideroblastic anaemia. Acta haemat. (Basel), 31, 9-23.

Lichtman, H. C., and Feldman, F. (1963). In vitro pyrole and por- phyrin synthesis in lead poisoning and iron deficiency. J. clin. Invest. 42, 830-839.

MacGibbon, B. H., and Mollin. D. L. (1965). Sideroblastic anaemia in man: observations on seventy cases. Brit. J. Haemat., 11, 59-69.

Mikołajew, M., Plachecka, M., Piotrowska, D., Galajowa, W.. and气ి Kopeć, M. (1966). Niedokrwistość $w$ przebiegu goćśca $\mathbb{D}$ przewlekłego. I. Częstośc wystepowania, cechy morfologiczne i przemiana żelaza. Reumatol. pol. , 4, 209-220.

Mollin, D. L. (1965). Sideroblasts and sideroblastic anaemia. Brit. J. Haemat., 11, 41-48.

Mouriquand, C. (1958). Le sidéroblaste. (Étude morphologique et essai d`interprétation). Rev. Hémat., 13, 79-99.

Mouriquand, C., Lejeune, E., Germain, D.., and Maitrepierre, J. (1962) Le fer médullaire dans les maladies rhumatismales. Nour. rev franc., Hemat.. 2, 55-69.

Owen, E. T., and Lawson, A. A. H. (1966). Nature of anaemia in rheumatoid arthritis. VI. Metabolism of endogenous iron. Ann. Rheum. Dis., 25, 547-552.

Pawelski, S., and Zawadzki, Z. (1958). Normy $i$ Stany Prawidlowe nO Medycynie Wewnetrznej. Państwowy Zakład Wydawnictw Lekarskich, Warsaw.

Prato, V., Mazza, U., Massaro, A. L., Bianco, G.. and Battistini, V. (1968). Porphyrin synthesis and metabolism in iron deficiency anaemia: II in vitro studies. Blut, 17, 14-19.

Schalles, O. (1958). In Standard Methods of Clinical Chemistry, N edited by D. Seligson, pp. 69-78. Academic Press, New York. O

Steiner, M., Baldini, M., and Dameshek. W. (1963). Heme synthesis N defect in 'refractory' anemias with ineffective erythropoiesis. ON Blood, 22, 810.

Vavra, J. D., and Poff, S. A. (1967). Heme and porphyrin synthesis in sideroblastic anemia. J. Lab. clin. Med., 69, 904-918. 